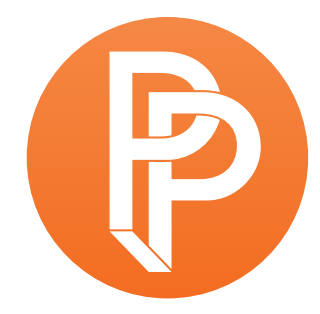

PERFORMANCE

PHILOSOPHY

\title{
LOVE IN THE TIME OF CRISIS: EXAMINING THE SUBJECT OF LOVE IN THE SOUTHBANK'S FESTIVAL OFLOVE (2016)
}

\section{RACHEL COCKBURN INDEPENDENT SCHOLAR}

I began to think about the subject of love a couple of years ago, in the summer of 2016. Each morning as I cycled over Waterloo Bridge, London, on the way to one of my various precarious employments, I would puff my way up the curved incline at the south end of the bridge. To the left, and towering above myself on the bicycle stood a gigantic banner on the wall of the Queen Elizabeth Hall, part of the Southbank Centre complex. One word: 'Love'. It was unavoidable-yet quite equivocal: at once a command-'Love!'; an ideal proclamation 'Love'; a question-'are you able to "Love"?'; an invitation-'Love...'; or a scoff and violent rejection-'Love'. Am I among the loved? No matter the mode of address, it called on the individual subject to, and of, love. My mode of subjection to this 'Love' depended, for sure, on the various forces, energies and affects driving me forward on any given morning.

Of course, there was, it turned out, more to this 'Love' than one single banner on the wall of the Southbank Centre. The banner was part of the larger Festival of Love (2016). And in the discussion to come, it is this festival that I interrogate. I do so in order to explore love: how love is understood, conceptualised, practised and, more often than not, taken for granted in its ubiquity in the social sphere. Through engaging with the festival, I challenge love understood as a universal ideal or ahistorical concept. By drawing on Foucault's theories of governmentality, I suggest an understanding of love as a regime: a governmentalised love, with particular loving subjects. Thinking love in this way, I turn to Gillian Rose's discussion of love and crisis. For Rose, crisis is inherent in democracy as a structure of governance, and attempts to mend crisis have been articulated through specific articulations of 'love' $(1992,164)$. By considering love in crisis, both historically and in the present socio-political context, I hope to begin to think love differently as an ethico-political practice-a love in krisis. 
To begin the discussion, I introduce the Festival of Love - a festival which ran annually from 2014 to 2016, covering the months of July and August. Given the summer period falling alongside UK school holidays, the festival had a strong emphasis on activities and events, particularly daytime events, for families, children and young adults. This could be seen in both the curation and use of the various indoor and outdoor spaces and performance and activity venues spread throughout the Southbank site, and in the selection of the activities and performances held during the festival. That being said, given the theme of the festival-love-adults, and particularly couples, had also been considered in the programming.

In the previous year, the festival had been set out around various conceptual understandings of love covering an extremely broad (and arguably rather simplified) range. As the festival programmers stated, whilst the Greeks had around 30 words to describe love, the Southbank Centre decided on 'seven of the most powerful'. This ranged from Agape (understood here as the love of humanity); Storge (here as family love); Pragma (the love which endures, a married couple, life friends); Philautia (self-respect, the love we give to ourselves); Philia (shared experience, the love when striving for a common goal); Ludus (flirting, playful affection, the fluttering heart and feelings of euphoria); and Eros (romantic and erotic love, based on sex and powerful magnetism) (Southbank Centre n.d.a.). Whilst time could be spent here considering why and how these particular concepts were narrowed down, the interesting point in terms of the discussion is the shift from 2015 to the following year. In 2016, while the festival no longer curated the program around these seven explicit categories, they evidently kept the same 'Love' ethos, but streamlined the categories a little further. Under the banner of 'Love'-and likewise the Love Flags, a work by Mark Titchner commissioned for the first festival in 2014, flown high on the riverfront terrace of the Royal Festival hall building - the various activities, performances and concerts throughout the festival were framed and punctuated by three over-arching events.

The first of these overarching events to take place was Encampment. This was organised by Good Chance Theatre and took place within the 'Good Chance Dome' on the Festival Terrace from 30 July to 7 August. As stated in the festival programme by Joe Murphy, one of the founders of Good Chance Theatre, the dome was originally a temporary theatre erected in the Calais Jungle (Southbank Centre, n.d.b) prior to the razing of the camp. For the nine-day event, this structure was rebuilt. The various events held within the dome were both work made by refugees and work about refugees. For example, Scattered, written by Tim Baker and presented by Theatre Clywd, was a play about a Syrian refugee relocated to Wales, and September 11th was a play written by Kuhel Khalid, a refugee living in the UK. Alongside live performance and theatre, there were film nights including screenings of films such as Queens of Syria (dir. Y. Fedda, 2014), a film telling the story of 50 women in exile from Syria who came to together in Jordan to perform Euripides' The Trojan Women, an Afghan kite-making workshop with Sanjar Qiam, and an exhibition of art by residents of the Calais refugee camp facilitated by artist Sue Partridge.

The second overarching event, Strive, was a three-day event held from Friday until Sunday, 5-7 August. The event was for those aged between 15 and 25, or as the program asks, 'were you born in the 90s? [...] [Y]ou grew up in a new age of digital technology and social openness, and your ideas 
and creativity will shape the next wave of culture and art' (Southbank Centre, n.d.b). The event focused on the learning of new skills and allowing those involved to 'showcase your talents and get a little bit closer to a bright and shiny future' (Southbank Centre, n.d.b). The events were split into four character-types that could be mixed and matched: thinker, speaker, dreamer, creator. To paraphrase the programming, the types were described in terms of certain actions and desires: thinker-mulling over deep thoughts and new ideas; speaker-happiest raising the voice to inspire other people; dreamer-loves to get lost in an artwork or performance; creator-wants to get creative right now (Southbank Centre, n.d.b). If you saw yourself as a thinker you could expect a program of events including a portraiture sitting and sketching workshop, spoken word performance, or a coding workshop. As a speaker you could engage in the secrets of beat-boxing or pitch ideas about the 'business of creativity' at the Young Entrepreneur 2016 event. The dreamer could watch performances by the National Youth Orchestra of Great Britain, explore classical ballet, or learn how to make a music track. And the creator might participate in tie-dye and screenprinting workshops, a performance by Scottish Ballet, a popping and locking session, or a girls' drumming workshop, whilst also picking up tips on making it big in Industry Bites.

The finale of the Festival of Love was marked by the Big Wedding Weekend, running from Saturday to Monday, 27-29 August. In the words of the festival this was 'a huge celebration of love with free events across the bank holiday weekend to celebrate the happy couples getting married as part of the big weekend' (Southbank Centre, n.d.b). Events covered a broad range of activities. Bridesmaid Dress Up offered the opportunity to 'experience the weekend dressed up in [one of the festival's] fabulous bridesmaid dresses' (Southbank Centre, n.d.b). The outfits were available to wear all of the Saturday, and wearers were encouraged to 'swish around the terrace in style' (Southbank Centre, n.d.b). Anniversary Message Eggs presented a 'drop-in workshop [which] offers everyone a chance to reflect on their years of love [...] a gift to celebrate your years together with a friend, family, member, colleague or lover' (Southbank Centre, n.d.b). Likewise, creative art and writing workshops such as Draw Your Love and Dedicating Words gave individuals the platform to demonstrate their love by performing their love to (or on behalf of) their loved one. For romantic couples, there was also the possibility of a romantic Date Night at the Archive, in which couples could 'spend a romantic evening in the archive studio working together with your other half to explore the Southbank Centre's archives' (Southbank Centre, n.d.b). Here, as with many of the workshops and events held in the public spaces of the Southbank throughout the festival, a number of the events were free of charge, whilst others were ticketed.

In setting out the aspects of the festival and the analysis to follow it is not my intention to assess or interpret the pleasure garnered and felt from those taking part in the festival, or to analyse the individual events or performances in terms of their value or merit. Rather, I am interested in this festival as an illustrative example of the way in which the idea of love is articulated and asserted as a universally shared concept. The ideas of love asserted in the festival take inspiration from ideas deriving from the Greeks. However, they also share the selective attitude that often exists toward Greek ideas that ignores the exclusionary nature and social reality of that historical period-for example, the fact that Greek love was designed primarily for and by elite male citizens, 
members of the polis. It is this selective attitude towards, and exclusionary nature of, the seemingly universal and essential love that I aim to interrogate.

\section{Governing love}

In 'Against Essentialist Conceptions of Love: Toward a Social-material Theory' (2015), Christian Lotz addresses the essentialist conception of love, set out most recently by contemporary philosophers such as Alan Badiou (Badiou \& Truong 2012) and Michel Hardt and Antonio Negri (2009). Here Lotz identifies a key flaw in essentialist approaches: they obfuscate 'material, historical, and the social form that love takes on in real individuals [...] formed by different interests determined by class positions' $(2015,132)$. In so doing, Lotz continues, 'Love' emerges as part of 'deeply ambivalent projects that lead to a mystification of love by giving it a metaphysical status' (ibid.), such that love exists beyond any particular socio-historical form and becomes 'ahistorical' (143). In contrast to this essentialist approach, Lotz argues for a 'social-material conception of love that is tied to its social form' (132) and addresses 'the real life activity of humans who reproduce themselves through and by these activities' (135). Here love is stressed as a historically contingent social form, and is certainly not prior to the social form the act of love takes. And, as Lotz goes on to stress, given the dominance of capitalism in Western societies, then it follows that the social form love takes is necessarily 'commodifiable' (139).

In setting out love as a commodifiable social form, there are two key aspects of particular interest in this discussion. Firstly, social divisions, such as class, are hidden by ideological structures which project a 'universal image of love as the intimate bond between two people that seems to transcend all class divisions' (140). That is to say, love is asserted as 'an ideal achievable for all classes' (ibid.). Moreover, this universal love is framed by 'a distribution of loving subjects that, in turn, are created as consumers of love products and activities related to these products' (141). One obvious example is that of online dating. Not only do we pay to exist as a profile on a platform-either through direct subscription charges or indirectly through means such as the farming of our personal data-but we also invest time, money, and labour in various ways to develop our selves physically, mentally, and professionally so as to be, at least algorithmically, love-able.

Secondly, Lotz highlights the contradiction inherent in commodifiable love: love is packaged as a romantic irrational idea, but is an increasingly rationalised and instrumentalised practice. For instance, think of all the therapy available to help you find out why your emotional faculties are not working properly. There is a reason you are unable to love and with the right support, expertise, the right technologies, and, of course, the financial capability, you will be love-able. Such a rationalisation of love is possible through the mechanisms of standardisation (141), and love is no exception: 'the more we experience our modern forms of love as "liberated", "independent" [...] the more we actually become dependent on capital itself [...] [and love's] increasing subjection to the commodity form' (140).

Here Lotz emphasises a crucial point in terms of love and individual subjection. To fully grasp the implications of this, I turn to the relation between love and governance of the self and others. By 
engaging with Michel Foucault's 'governmentality' (Foucault [2004] 2009), and the recent articulation of this concept by Mitchell Dean (2010), love can be understood, not only as a commodifiable social form, but as a regime of love. And moreover, the 'love' of the Southbank Festival will be shown to operate within such a regime.

Whilst it is not my intention here to offer a full analysis of governmentality, I do now want to briefly set out the key aspects most pertinent to this discussion. Firstly, Foucault understands governmentality as the specifically modern mode of governance, emerging contemporaneously with the constitution of 'population' as an object and subject of discourse during the eighteenth century (Foucault 2009, 66). 'Population' becomes understood as a 'multiplicity of individuals who [...] exist biologically bound to the materiality within which they live' (21), involving a specific relationship between the individual and the collective, the everyone and every 'one'. With the prevalence of the idea of 'population', the specific concern in political practice and theories of government becomes the 'set of processes [of life-such as birth, labour, leisure, education, illness] to be managed at the level and on the basis of what is natural in these processes' (74).

Governmentality, then, is the art of governance constituted through 'the ensemble [complex assemblages or regimes of practices] formed by institutions, procedures [...] calculations, and tactics' (108) that exercises a specific and complex form of power. This art of governance 'has the population as its target, political economy as its major knowledge, and apparatuses of security as its essential technical instrument' (ibid.). Governance is no longer one based on sovereign obeisance, whereby the individual political agent or a collection of subjects of right must obey the sovereign's will, but one of management of the 'naturalness' of the population. Mitchell Dean (2010) usefully identifies the rationality of this governance with that of liberalism, ${ }^{1}$ obeying only one rule: the 'rule of maximal economy' (73). And, importantly, governance and the articulation of sovereignty is immanent, and dispersed within, the population itself. This shift to an immanent understanding of sovereignty, the state, and the individual, without an external authority, Foucault terms the "'governmentalisation" of the state' (Foucault 2002, 220).

Broadly speaking, this modern art of governance-governmentality-acts on two inter-relating levels. First, the practices of government exercise a form of power at the level of the population as a whole, whilst the second level is that of the individual. Here, governance is enacted through ethical practices of the self. These ethical practices of the self, which I make the primary focus in the discussion to follow, are individualising practices of self-governance, or that which Foucault terms: 'the conduct of conduct' (41). This mode of self-governance is outlined in four aspects: the what, the how, the who, and the why, and can be articulated as follows: first, the ethical substance to be worked on (for example, 'the flesh' in Christianity, or 'pleasure' in Ancient Greece); second, the way individuals are incited or invited to work on their conduct through a particular set of practices-ascetics_of the self; third, the recognising of the ethical subject who is in need of transformation (for example, one prone to weakness of the flesh, or the contemporary jobseeker); lastly, teleology, addressing why we govern ourselves, the goals or ends to be achieved, whether that be, for instance, Christian salvation, the virtuous life, or the productive life (Foucault 1997, 265). 
Having briefly set out the key aspects of the ethical practices of the self intrinsic to governmentality, I return now to the Festival of Love. My aim is to point to the ways in which we might begin to understand the festival as a practice of governmentalised love, immanent and mediated as part of the social sphere. Here love is articulated not only as the commodifiable social form Lotz sets out, but as a regime of love that incites and facilitates ethical practices of the self, which, in turn, constitute particular loving subjects.

The focus for the Big Wedding Weekend was quite clearly 'the couple'-either those who have shared lives together so far, or the future aspiration to be not only one, but part of a couple-a two. It is not my intention here to argue against coupledom; for most people, being alone is a difficult and lonely mode of being and many would (and do) choose to be part of a two. That being said, there are aspects to interrogate within the Big Wedding Weekend. First, the couples (or hopeful individuals) become performing loving subjects who make their love productive in a double sense, they produce what they consume-or, to draw on Jen Harvie $(2013,50)$, they become 'prosumers'. Love is also productive for others within the social totality of which they are part-in this case, the stage of the event in the Southbank Centre (whether that be a creative workshop, dance, or date night). In this way, a performance of loving subjects produces love to be consumed not only by themselves, but also by others. Moreover, if we begin to consider the possibility of governmentalised love, the couples (or hopeful individuals) can be understood as 'loving subjects', articulated and governed within a particular regime of love, and within particular ethical practices of the self. Through various practices they demonstrate their love, practices that are identifiable to others through established social norms. Couples perform and present their love for themselves, each other, other couples, and single individuals, a performance which is celebratory, aspirational, and teleological. Not only do loving subjects produce love to be consumed, but modes of conduct are asserted for, and practiced by, the loved, the unloved and the (un)love-able.

Strive, in a sense, was a whole weekend dedicated to the self-realisation of the individual (aged between 15 and 25) in achieving a 'bright and shiny future' (Southbank Centre, n.d.b) through the love of work. Putting the religious and salvationary undertones to the side here for the moment, the thing to note is the bright and shiny futures on offer (or at least the aspiration for such a future, a telos) are firmly centred on a particularly privileged type of work-that is, aspirational, creative, artistic, intellectual modes of labour. On sale here is the aspiration to do work you love. If you work hard and aspire enough (this vision promises) you can be one of the chosen few, one of those saved from other non-creative, non-thinking, non-speaking modes of labour. Strive and you will love your work, and love someone else who will at least partly love 'you' because of who 'you' are as a social subject. Also in Strive we see the very thing Lotz asserts-the dissimulation of class (social) divisions, and the assertion of the 'universal image of love as the intimate bond that seems to transcend all class divisions' $(2015,140)$, the universal 'ideal achievable for all classes' (140).

The 'intimate bond' that is on offer here, however, is not only the bond between those in a romantic couple, as in the Big Wedding Weekend, but that between love of-or through-work and the individual. In fact, the Strive weekend is a contemporary re-packaging of the privileged cultural worker originally set out by Schiller over two centuries ago in On The Aesthetic Education of Man 
(1794). Of course, the present socially lived experience for many is quite different. For example, it is widely recognised, at least in the UK, that if you aspire to a career that is attractive to many, often the only possible way of reaching the goal of work you love is through acquiring thousands of pounds worth of debt for a specific education (current HE undergraduate fees stand at an average of $£ 9,000$ p.a.), ${ }^{2}$ or being in a position to undertake an unpaid internship and engage in unpaid labour. Love is work.

Considering the festival in this way, the various aspects of the 'ethical practices of the self' become evident. The ethical substance to be worked on is love. The particular set of practices of the self are those to work on and transform the individual into a loving subject, someone who is loveable-whether that be through the displays of romantic love in the Big Wedding Weekend, or the love of work in Strive. And the aim, the telos, of love is love, an indefinite and infinite love that will always require continuous work to attain and maintain. ${ }^{3}$

By thinking through the Festival of Love, what also becomes apparent are the ways in which the ethical government of the self and the wider practices of government are intertwined through love. Here I point only briefly to two key mechanisms in order to indicate this intertwining governance. First, the concept of marriage put forth in the Big Wedding Weekend enacts a key mechanism in the practice of government: the law. This presents us with the contradiction between the equality posited through law, that is, everyone is equally free to marry (here I am referring to the UK and EU legal context), and the reality of who this 'everyone' actually includes and excludes. However, specifically in terms of this discussion, law in modern modes of governance operates more and more as a regulatory principle, a 'norm' (Dean 2010, 142). And as Mitchell Dean makes clear: 'the norm creates an equivalence in that all are comparable in relation to it, but it also creates differences and inequalities in so far as it enables each to be individualised and hierarchically ordered' (141). ${ }^{4}$ Certainly the Big Wedding Weekend sets out normative practices, the most obvious one being the offer of the opportunity to swish around in a traditional bridesmaid dress. Love is normalised as marriage, along with the social hierarchy (intersecting on various lines of class, race and gender) established between the married, the partnered, and the single.

The second key mechanism I will point to is found in the third umbrella event, Encampment. As described above, Encampment addressed and highlighted the plight of the millions of refugees involved in what has been termed the 'refugee crisis', and this can certainly be understood as a positive and worthwhile project. The visitors and participants played their part in acknowledging and celebrating the creativity of those who find themselves in adverse conditions, the power of art within the midst of crisis, and the difficult relationships that must navigate difference between cultures. Even so, there is an evident disjuncture between people out for a day of leisure or an evening by the river, having a glass of white wine and nibbles, whilst they take in the plight of refugees and the 'crisis'. The refugee crisis being represented in a cultural institution nestled on prime real estate on the banks of the river Thames in central London brings out two stark contradictions fundamental to capitalist societies: firstly, the supposed formal equality of individuals under the law and the actually existing social inequality, and, secondly, that between the notion of universal human rights and the rights of the citizen. ${ }^{5}$ 
However, the specific mechanism I aim to highlight here can be understood through the choice of caritas as a concept of love in the festival. Caritas is most often defined as the love of humankind, or, in everyday language, charity. Yet the caritas on the Southbank has arguably been given a particular ontological investment: philanthropy. And as Dean has argued, philanthropy has been a key mechanism of modern liberal modes of governance in that it normalises social problems. An example of this offered by Dean is in his work The Constitution of Poverty (1991), which highlights philanthropy's role in the normalisation and inclusion of poverty in England during the 19th century as a necessary corollary of capitalist accumulation of profit. Certainly, the presence of refugee crises throughout the 20th and 21st century can be argued to be co-existent with, and normalised within, the globalised capitalist drives for economic growth at any cost.

In briefly setting out these aspects of the festival, what begins to become identifiable is an object and subject of 'love', discursively articulated through complex assemblages of knowledges, practices, technologies, and mentalities. Through the concept of governmentality we can consider the governmentalisation of love: a regime of love that is tied to the governing of the self and the governing of others, dispersed and mediated within various social sites. And this love is intrinsic to modern liberal governance, inciting and articulating specific loving subjects, whilst following only one internal rule: the rule of economy.

In considering governmentalised love in this way, the question of love and the political arises. Specifically, the political implications of governmentalised love become apparent if we consider the presence of love in crisis, that is, in periods of crises of governance and civil society. In times of crisis, love is often invoked as a concept to overcome the crisis: for example, the claims for communist love in the revolutions of the latter part of the 19th and early 20th centuries; or 1968 and 'the Summer of Love' that emerged in response to the social crisis during the Vietnam War, the split between the ethical authority of the state and society. If love emerges in the public sphere during periods of social crisis, what is this love doing? What is love's ambition? With this in mind, I turn now to Gillian Rose's discussion of love, which, for Rose, is at the heart of politics.

\section{Love in crisis}

In the section of The Broken Middle (1992) entitled 'Love and the State', Gillian Rose reiterates what other philosophers have identified before her: that the relation between the universal, the singular, and the particular is 'the political difficulty' (164), or, more specifically, where politics arises. In other words, the difficulty is the formation of the political will; the will of the individual, the collective will of the 'people', and the aporetic relation between the two. ${ }^{6}$ Whilst in Rose's view, the difficulty is triune (the universal, the singular, and the particular), it has most often been seen in binary oppositions, as in the 'us' and 'them' logic of much political discourse. It is these oppositions that 'we invariably attempt to mend', and we do so with 'love, forced or fantasised into the state' (xii). Here love is placed at the heart of the political difficulty. This love, Rose argues, poses a double danger: 'a posited communal love [that] translates into social violence of individuals, and an agapic protestant inwardness [that] affirms hypocritical individualism' (157). This double danger of love forced or fantasised is, for Rose, understood as pietistic politics. 
To expound the double danger of pietistic politics Rose turns to Max Weber, whose The Protestant Ethic and the Spirit of Capitalism ([1905] 2011) can be understood precisely as a concern with this same double danger. For Weber, pietistic doctrines of salvation offered an individual greater confidence of being one of the saved, one of those chosen for God's predestined love. This was enacted through pietistic transformative practices of the self which governed individual spontaneity and shaped how the self externalised itself as an individual subject (Weber 2011, 126). In this way, Pietism was an ascetic, one that shaped an ethic of conduct of oneself and others.

In Weber's account, two love ethics can be identified. Firstly, the love ethic which emerges through the 'sect' community: a delimited group of individuals that denied the world beyond their specific community and followed a rigorous ethical conduct, determined in, and by, the specific community (149). Ernst Troeltsch, a contemporary of Weber, termed this the 'sect spirit' (Troeltsch [1911] 1981, 357). For Troeltsch, the lasting influence of the 'sect spirit' was a 'radical individualism and the radical ethic of love combined against the church type' (378). The second love ethic is found in the Protestant ethic, grounded on a vocational calling through which the individual carried out 'brotherly love' in the world (Weber 2011, 146). In Weber's view, the Protestant ethic allowed for a mode of conduct based on a more worldly ethos, specifically a 'middle class vocational ethos built on clear conscious and economic gain', that is, 'one of moralism and charity' (158).

These two ethics of pietistic religion place the individual in a relationship to God's love, either through the radically inward agapic relationship, or the ethical immediacy of a community of love. Both required an ascetic movement, a transformative practice of self, a love ethic, that constituted the individual as a particular loving subject. For Rose, these two forms of love ethic continue in modern societies in the form of pietistic politics. Specifically, in a crisis predicated on the separation of civil society and the state, two 'flights' of love become evident in the ambition to mend the split: 'to opt for individual inwardness or local [love] community' (Rose 1992, 165). These two flights, that see love forced or fantasised into the state, are the transformative ethical movements, with love at the heart. As examples of love's ambition to mend the split of modern civil society and the state, Rose sets out three periods of crisis-the crises of bureaucratic reform at the end of the 18th century, social democratic defeat in pre/post-World War I, and the rise and fall of fascism of pre/post World War II. Rose does so by drawing on three women authors: Rahel Varnagen, Rosa Luxemburg, and Hannah Arendt.

Varnagen articulates the crisis of bureaucratic reform at the end of the 18th century. As a Jew and a woman, Varnagen was witness to (and at the same time excluded from) the emergent modern bureaucratic 'nation' state (196), specifically the German nation state. She confronted the pietistic love ethic of fraternity (the love of fellow men) and the Christian love community. The early work of Luxemburg is situated in the crisis of social democracy in pre/post-World War I Europe. Here, the danger lies in the 'corruption of bourgeois morality' (203); the individual inwardness of revisionism, and the 'culture of terror' (ibid.); the totalising ethical community of nationalism or centralism. Arendt articulates the third period of crisis, the rise and fall of fascism of pre/postWorld War II. 
As Rose astutely points out, Arendt's earlier work, including the first two sections of The Origins of Totalitarianism (1951), ${ }^{7}$ rightly identifies the potential violence in love of a 'nation' or a 'nation-state'. This is done initially by interrogating the historical diremptions of the state and civil society in the late 19th century and early 20th century and the accompanying contradictions, whilst, at the same time, resisting overcoming or resolving these contradictions in love of a nation, race, or nationstate. ${ }^{8}$ However, of most interest in terms of the present discussion is the shift in Arendt's position. For Rose, Arendt's later work, which most explicitly addresses her own experience of the rise of fascist governance and totalitarian ideology, presents an idealised and transhistorical concept of the political realm modelled on the Greek polis and the Roman res publica. ${ }^{9}$ This idealised concept is contrasted with the "rise" of the debased realm of the social' (231), that is, the modern social realm: society. Here Arendt faces a problem: if the modern debased social realm is not the space of political action, then where exactly is the space? Arendt overcomes this difficulty by taking flight into St Augustine's agapic love.

Drawing directly on St Augustine's agapic love, Arendt articulates the modern human being as an apolitical 'mere existence', one that is 'mysteriously given us by birth' and 'can be adequately dealt with only by the unpredictable hazards of friendship and sympathy, or by the great and incalculable grace of love, which says with Augustine, "Volu ut sis" (I want you to be)' (Arendt [1951] 1976, 301). In setting out the incapacity of individual political action in the modern world, the promise of political action is placed in 'a new beginning', that is, 'each new birth' (478-9). Here, Rose argues that Arendt conflates the 'miracle of each new life' with 'socially developed and recognised differences, the equality and inequality which are historical constructions and which political institutions may equally seek to abolish' (Rose 1992, 226). The modern crisis of the rise of fascism and totalitarianism to which Arendt is witness arguably leads her to opt for an apolitical and transhistorical agapic love.

\section{A krisis of love}

Taking into consideration Rose's discussion of love in crisis and the dangers love poses, we might then ask, as Rose herself does not, ${ }^{10}$ what the ambition of governmentalised love is, and how might this be thought of in terms of the context of the Festival of Love. In the summer of 2016, with the refugee crisis impacting hugely throughout Europe, nationalism, populist rhetoric and political movements were rising vehemently in various European countries. And in June of that year, the EU referendum in the UK resulted in a vote for leaving the EU. The result of this vote, whilst shaped by complex factors, was driven at least partly by love for a certain ideal 'nation'. Likewise, the UK government immigration and austerity policies set up to create a 'hostile environment' within the UK itself were in full operation by the summer of $2016 .{ }^{11}$ At the time of writing this article June 2018) the consequences of these governmental decisions have come to violent fruition. ${ }^{12}$

Considering this wider context of crisis, what the Festival of Love arguably presents is a depoliticised love ethic asserting both individual love, and the articulation of a love community. At the same time, the exclusion and social inequality inherent in the reality of such a community of loving subjects is normalised (through mechanisms such as philanthropy) and obfuscated (through 
practices such as those targeting individual self-development and self-fulfillment). If, as Rose argues, love is called on to mend in a period of crisis, then the ambition of governmentalised love, evident on the Southbank, is centred on the pacification of the social sphere, ${ }^{13}$ and the management of the individual subjects that exist within it. The two flights of love (the individual agapic love and the love community), understood through the lens of Foucauldian governmentality, can be seen as intertwining individualising and totalising practices that manage the individual in order to constitute a particular loving subject situated within a depoliticised social sphere: a subject that 'is either divided inside himself or divided from others' (Foucault 2002, 326). Here we have a specific articulation of the aporetic relationship between the everyone and the every 'one', the crisis at the heart of democracy which Rose emphasised.

Who, what, how, and why we love are intertwined and worked on through complex practices, knowledges, and mentalities of love that, for the most part, remain unquestioned, yet shape how we exist in the world, how we shape the world in which we live now and aspire to in the future. If so, then we need to ask where does this leave the space for political action? What kind of political subjects are we, and what kind of world is aspired to, through governmentalised love? Certainly, these questions need to be considered in relation to the emergence of political protests explicitly involving 'love' as a political tool. One well known example here is the 'Love Trump[']s Hate' and \#lovetrumpshate protests emerging in 2017 in response to the election of Donald Trump as president of the US. Whilst the 'love' in the protest might allow people to join together in a symbolic rejection of the protest's target (that of the election of Trump), it is questionable what this love offers beyond a symbolic universal ideal, and likewise, whether it offers, in any way, an alternative to the pietistic love ethics identified by Rose.

To draw one final time on Dean, by giving our attention to love, we can gain an understanding of a love regime that 'tr[ies] to shape, sculpt, mobilize and work through the choices, desires, aspirations, needs, wants and lifestyles of individuals and groups' (Dean 2010, 20). By understanding 'love' in such a way, we might also begin to identify its limits and, importantly, its contingent nature (14). With this in mind, I finish with the thought of how, and to what extent, it is possible to think, and do, love differently in this current period of social and political crisis. As Lotz $(2015,147)$ asserts: 'Instead of thinking about love in terms of a truth procedure or ontological event, we should see its social character and thereby turn our attention to its particular social productivity'. Love in crisis renders palpable the contingency of ambitions to mend through force or fantasy. This opens the possibility of an ethico-political practice-a krisis of love-that articulates differently the loving relationship between the individual and the collective. 
1 Three points are useful to note in regards the liberal mode of governance identified here. First, the 'free' subject asserted by liberalism is a situated subject free to make choices within a regulated and managed sphere (Dean 2010, 193). Second, as Foucault stressed throughout his work on modern governance, and Dean takes up, liberalism is a rationality that takes various forms, the variant forms of liberalism, and indeed of neo-liberalism, stem less from fundamental philosophical differences and more from the historical circumstances and styles of government' (74). Third, liberal modes of governance always 'contain the possibility of non-liberal interventions' (163).

2 For a fuller discussion on the relationship between debt and governmentality see Lazzarato (2015).

${ }^{3}$ It is interesting here to consider the infinite nature of love in relation to capitalism's infinite aim of the accumulation of profit. See, for instance Harvey $(2011,28)$.

${ }^{4}$ For a fuller account of liberalism and the law see Dean's section on 'Law and the Norm' (2010, 140-146)

${ }^{5}$ Hannah Arendt set out these very contradictions in her seminal work on 'Imperialism' in The Origins of Totalitarianism (1976).

${ }^{6}$ Rose offers a definition of 'aporia' as follows: "While "contradiction" is a logical term, which, applied to social structure, implies possible resolution, "aporia" is prelogical, it refers to a lack of way, and implies no exit from its condition' (206, note 212). It is this sense she talks of the 'aporia between the everyone and every "one'" (164).

${ }^{7}$ It is useful to bear in mind here Rose's comment on the publishing context of Arendt's work as it is often overlooked: 'The Origins of Totalitarianism has been received largely as a cold-war, anti-Marxist work on "Totalitarianism", the title of the third of its three parts, each first published separately, when it will be argued here that Part One, "Anti-Semitism", and Part Two, "Imperialism", may be seen, respectively, as the most sustained attempt to develop Marx's account of the split between state and civil society [...] and to provide a political and sociological history of the modern "nation"-state.' (Rose 1992, 217)

8 The two contradictions referred to here are as follows. The first contradiction is in the premise of equality of all individuals before the law and the social reality of a society based on inequality. The second contradiction is that between the 'state' which is subject to law and the declaration of the rights of man, and that of the 'nation' which presupposes a sovereignty subject to no law (Rose 1992, 220)

${ }^{9}$ For a full account of this idealised concept of the political realm see Arendt (1998).

10 Rose's philosophical work and thinking emerges from a speculative reading of Hegel and the Hegelian dialectic.

${ }^{11}$ For further information on the 'hostile environment' see Liberty (2018).

12 One such consequence is the Windrush Scandal. For a brief outline of the Windrush scandal and its relation to the 'Hostile Environment' policies see Amnesty International UK (2018).

13 This ambition can best be understood in relation to the irreconcilable 'problem of society' that is inherent to modern modes of liberal governance. To quote Dean: The problem of society arises from the liberal problematic of security [...] [that is] How can we attain security (a pacified totality) in a milieu constituted by radically heterogenous forces, processes and types of subject?' (Dean 2010,148).

\section{Works Cited}

Amnesty International UK. 2018. 'Seventy Years After Windrush'. https://www.amnesty.org.uk/blogs/yes-ministerit-human-rights-issue/seventy-years-after-windrush. Accessed 4 June 2018.

Arendt, Hannah. (1958) 1998. The Human Condition, second edition. Chicago: University of Chicago Press. https://doi.org/10.7208/chicago/9780226924571.001.0001

(1951) 1976. The Origins of Totalitarianism. London: Harvest. 
Badiou, Alain and Truong, Nicolas. 2012. In Praise of Love. London: Serpent's Tail.

Dean, Mitchell. 2010. Governmentality: Power and Rule in Modern Society, second edition. London: SAGE.

1991. The Constitution of Poverty: Toward a Genealogy of Liberal Governance. London: Routledge.

Foucault, Michel. 2009. Security, Territory, Population. Lectures at the College De France 1977-1978. Translated by Graham Burchell. Basingstoke: Palgrave Macmillan.

___. 2002. Power, Essential Works of Foucault 1954-1984, Volume 3. Edited by James D. Faubion. Translated by Robert Hurley et al. London: Penguin.

1997. Ethics: Subjectivity and Truth, The Essential Works, Volume 1. Edited by Paul Rabinow. Translated by Robert Hurley et al. London: Penguin.

Hardt, Michael, and Antonio Negri. 2009. Commonwealth. Cambridge, MA: Harvard University Press.

Harvey, David. 2011. The Enigma of Capital and the Crises of Capitalism. London: Profile.

Harvie, Jen. 2013. Fair Play: Art, Performance and Neoliberalism. Basingstoke: Palgrave Macmillan. https://doi.org/10.1057/9781137027290

Lazzarato, Maurizio. 2015. Governing by Debt. Translated by Joshua David Jordan. South Pasadena, CA: Semiotext(e).

Liberty. 2018. A Guide to the Hostile Environment. https://www.libertyhumanrights.org.uk/sites/default/files/HE\%20web. pdf. Accessed 3 June 2018.

Lotz, Christian. 2015. 'Against Essentialist Conceptions of Love: Toward a Social-material Theory'. In Thinking about Love: Essays in contemporary continental philosophy. Edited by Diane Enns and Antonio Calcagno, 131-148. University Park: Pennsylvania State University Press.

Rose, Gillian. 1992. The Broken Middle. Oxford: Blackwell.

Southbank Centre, n.d.a. "The Seven Kinds of Love". https://www.southbankcentre.co.uk/whatson/festivalsseries/festival-love/seven-kinds-love. Accessed May 2017.

Southbank Centre, n.d.b. What's on: Festival of Love [brochure]. London.

Troeltsch, Ernst. (1911) 1981. The Social Teaching of the Christian Churches, Volume 1. Translated by Olive Wyon. Chicago: University of Chicago Press.

Weber, Max. (1905) 2011. The Protestant Ethic and the Spirit of Capitalism. Translated by Stephen Kalberg. New York: Oxford University Press.

\section{Biography}

Rachel Cockburn is an independent scholar, teacher and student cellist, based in London, UK. Her research is situated within the field of performance philosophy, specifically the intersection of philosophy, political theory, and aesthetic practice, and she holds a PhD (2015) form the University of London. Rachel has a number of published works, including recent chapter contributions in Performing Antagonism: Theatre, Performance, \& Radical Democracy (Palgrave Macmillan 2017) and Performing Interdisciplinarity (Routledge 2018).

\section{(c) 2018 Rachel Cockburn}

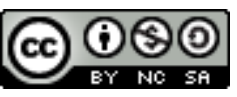

Except where otherwise noted, this work is licensed under a Creative Commons AttributionNonCommercial-ShareAlike 4.0 International License. 